\title{
The Penology of Islamic Criminal Law: Reintroduction of Islamic Penology
}

\author{
Marli Chandra
}

\begin{abstract}
The Penology of Islamic Criminal Law: Reintroduction of Islamic Penology. The justification for punishment is an interesting topic and undying debate among the scholars. Those who in favor of traditional approach would state that punishment is retributive in nature, whereas the opposite party would declare that punishment is for future benefits either particularly for offender or society in general. In this article, the researcher will elaborate the penological approach of punishment in Islamic criminal law. This study applies a comparative analysis based on the qualitative approach to compare the concept of punishment and its justification in the modern penology as well as in Islamic perspective. The study finds out that the justification for punishment in Islam, which is mainly contained in the hudûd and qishâsh offenses, does not deviate from what is understood by modern penology. Islamic law provides harsher punishment for serious offenses, but at the same time, it also prescribes ways on how to reduce such punishments.
\end{abstract}

Keywords: penology, Islamic criminal law, hudûd, qishâsh, jarîmah

\begin{abstract}
Abstrak: Penologi dalam Hukum Pidana Islam: Memperkenalkan Ulang Penologi Islam. Justifikasi terhadap hukuman merupakan topik perdebatan abadi dan menarik di kalangan para intelektual. Mereka yang mendukung pendekatan tradisional akan menyatakan bahwa hukuman bersifat retributif, sedangkan pihak yang berseberangan akan menyatakan bahwa hukuman adalah untuk kepentingan di masa depan, terutama bagi pelaku atau masyarakat pada umumnya. Dalam artikel ini, peneliti menguraikan pendekatan hukuman dalam hukum pidana Islam. Penelitian ini menerapkan analisis komparatif berdasarkan pendekatan kualitatif untuk membandingkan konsep hukuman dan pembenarannya dalam penologi modern serta dalam perspektif Islam. Studi ini membuktikan bahwa pembenaran untuk hukuman dalam Islam, yang sebagian besar terkandung dalam pelanggaran $\underline{h} u d \hat{u} d$ dan qishâsh, tidak menyimpang dari apa yang dipahami oleh hukuman modern. Hukum Islam memberikan hukuman yang lebih keras untuk pelanggaran serius, tetapi pada saat yang sama ia juga mengatur cara bagaimana mengurangi hukuman tersebut.
\end{abstract}

Kata Kunci: penology, hukum pidana Islam, hudûd, qishâsh, jarîmah 


\section{Introduction}

In daily life, an individual cannot live by himself: there is a tendency in the nature of each and every individual to form social relationships with other individuals. Wherever human beings exist, there exists a group or society. Aristotle was perhaps, the first thinker who called a man a social animal. ${ }^{1}$ Muslim scholars went further and discovered that man is, in fact, a political being who always lives in groups politically organized under some kind of law and political authority. Farabi was one of those earliest Muslim thinkers who highlight the political nature of human being. ${ }^{2}$ What is necessary for the existence of this relationship is certain predictability of action, a certain shared understanding. It is contended by Simon Roberts in his book Order and Dispute, that: At the root of everyday life in any society there must necessarily be some patterns of habitual conduct followed by the members, providing the basis upon which one member will be able to predict how another is likely to behave under given circumstances or how his own actions will be received. ${ }^{3}$

Furthermore, one theory of the creation of a state explains this relation by which its people submit part of their freedom in exchange for the protection of their rights. In order to preserve and maintain the equal distribution of these rights, the state in which those people lives should have a set of rules that will govern their activities. Then, if an individual does not have a set of rules that govern their action, is it possible that a social structure could be maintained? The answer is negative, as Honore has recognized that a social structure cannot stand if the rule "Everyone is to do as he or she likes". ${ }^{4}$

\footnotetext{
${ }^{1}$ Mahmood Ahmad Ghazi, State and Legislation in Islam (Shariah Academy, International Islamic University, 2006), p. 1.

${ }^{2}$ Abû Nashr Muhhammad al-Fârâbî and Rafael Ramon Guerrero, El Camino de La Felicidad (Editorial Trotta, 2002), p. 117-119.

${ }^{3}$ Christopher Harding and Richard W. Ireland, Punishment: Rhetoric, Rule, and Practice (Routledge London, 1989).

${ }^{4}$ Christopher Harding and Richard W. Ireland, Punishment: Rhetoric, Rule, and Practice, p. 80.
} 
In order to secure the obedience of the individuals and respecting of the rights of other, the transgression of such rules should liable him or her to a particular act that involves the disapproval from society and contains pain and unpleasantness. When we look at the practice of punishment, it may still safely assert that more punishment is handed down by families, the institution of work, education, and within the interpersonal sphere rather than is dealt out by the state. It may be said that the scope of punishment is involved in three spheres, namely: legal penalty, ${ }^{5}$ it is where the state has the power to inflict punishment to those who break its law. Secondly, it is, too supernatural and eschatological penalty, where punishment resides in a system of belief related to normative order. Lastly, popular penalty, which punitive reactions spring from community's standard of rules distinct from that represented by the state. ${ }^{6}$ Punishment may be applied by a number of different 'authorities' in relation to a single instance of offending conduct concurrently disapprove within a number of social groups. In regard to our discussion, it is limited to the sanctions imposed by the institution of criminal justice and their ancillary agencies. This focus should not be taken to deny the existence, or political importance, or other non-legal forms of sanctioning such as occur in, for example, domestic, education or employment. Punishment in the gist of state institution may not much different than other social penalties, in the context of social control: the difference may exist in the forms of measures applied, the associated procedures and organizational paraphernalia and the ambit of society itself. All groups within society with its distinct normative system and capacity should abide by state rules. ${ }^{7}$

${ }^{5} \mathrm{~J}$ Willday, 'Understanding Justice: An Introduction to Ideas, Perspectives and Controversies in Modern Penal Theory', Crime Prevention and Community Safety, 1.1 (1999), p. $80-81$.

6 Christopher Harding and Richard W. Ireland, Punishment: Rhetoric, Rule, and Practice, p. 38-43. 


\section{Islamic Law (Ahkâm al-Sharî’ah)}

Islamic law (al-Sharîah) ${ }^{8}$ in its nature is different from man-made law. From the beginning, it has been completed. Islamic law does not begin with a few rules that are gradually reaped and refined by the cultural process, but was comprehensively revealed to Prophet Muhammad (Saw) during his twenty-three years of prophethood "... This day, I have perfected your religion for you, completed My favor upon you, and have chosen for you Islam as your religion..."?

The purpose of Islamic law is for the well-being of mankind and is not confined to a particular community or territory, nor exclusively for Muslims only, but for other religions and communities who live in the Muslim community. This may be drawn from various verses in the Qur'ân and traditions of the Prophet (Saw), to quote some:

And We have not sent you (O Muhammad Sallallâhu Alaihi wa Sallam) except as a giver of glad tidings and a warner to all mankind, but most of the men know not.

And it is strengthened by the hadith that express the universal prophecy of the prophet Muhammad (Saw):

Narrated from Jâbir bin 'Abdullâh Radhiya Allâh Anhu that The Prophet SHallallâhu 'Alaihi wa Sallam said, "I have been given five (things) which were not given to anyone else before me; (1) Allah made me victorious by awe, (by His frightening my enemies) for a distance of one month's journey (2) The earth has been made for me (and for my followers) a place for offering shalât (prayer) and a thing to purify (tayammum),

${ }^{8}$ By definition, Islamic law (Ahkâm al-Sharîah) have been defined by jurists as kitâb Allah Tảalâ al-mutáalliqah bi af'âli al-mukallifin iqtidhâan aw tahyîran aw wadh'an. (A communication from Allah, the exalted, related to the acts of the subjects through a demand, option or through a declaration). In this definition, the law is classified into two major parts, one is primary $(\mathrm{hukm}$ al-taklifi) the other is secondary (hukm al-wadh'iyyu). It is similar to what was proposed by Hart in his book "The Concept of Law" in which he divided law into two main classifications, primary and secondary. Primary rules are concerned with the actions that individuals must or must not do, while secondary rules are concerned with the primary rules, they specify the ways in which the primary rules may be conclusively ascertained, introduced, eliminated, varied, and the fact of their violation conclusively determinate. H. L. A. Hart, Postscript, The Concept of Law, Edited by Penelope A. Bulloch and Joseph Raz (Oxford: Clarendon Press, 1994).

9 Ismail Poonawala, 'Wealth and Poverty in the Qur'an and Traditions of the Prophet, and How Those Concepts Are Reflected in the Rasa 'il Ikhwan al-Safa", Journal of Shi'a Islamic Studies, 8, no. 3 (2015), p. 263-87 <https://doi.org/10.1353/isl.2015.0032>. 
therefore anyone of my followers can offer shalat wherever he is, at the time of shalat (3) The booty has been made halal (lawful) to me yet it is not lawful to anyone else before me (4) I have been given the right of intercession (on the Day of Resurrection) (5) Every Prophet used to be sent to his nation only but I have been sent to all mankind. ${ }^{10}$

Moreover, the Qur'an also stresses that the revelation is for the guidance of humankind in this world:

... And We have sent down to you the Book (al-Qur'ân) as an exposition of everything, guidance, a mercy and glad tidings for those who have submitted themselves (to Allah as Muslims). ${ }^{11}$

Islamic law covers all aspects of human life, regulating personal matters and individual problems as well as those of the government and state. Islamic law is meant for all times and is valid as long as there are humans on earth "... This day, I have perfected your religion for you, completed My favor upon you, and have chosen for you Islam as your religion ...". ${ }^{12}$ Every person who embraces Islam as his religion means that he has agreed to adhere to the law $(A \underline{h} k \hat{a} m)$ ordained by Allah Swt. It is like a contract: when it is agreed upon, all matters that contain in such contract should be performed and where a party fails to perform his duty and obligation, he is liable to be punished.

\section{It's Classifications and Purposes}

Islamic criminal law may be divided into two major categories, i.e. fixed law ( $\underline{h} a d d$ or $\underline{h} u d \hat{u} d)$ and flexible law (ta'zîr). All laws are based the Qur'ân and Sunnah of the Prophet (Saw) as elaborated in the verse of the Qur'ân "The hukm belongs to Allah alone."13 This âyah determines the character of Islamic law and gives direction to all interpretations and ijtihâd. ${ }^{14}$ By the word of Nyazze ${ }^{15}$ it is like an ever-growing tree.

${ }^{10}$ Al-Bukhari, Sahih al-Bukhari. Trans. Muhammad Muhsin Khan. (Riyadh': Saudi Arabia: Darussalam Publication, 1997), p. 584-6.

${ }^{11}$ Q.s. al-Nahl: 89.

${ }^{12}$ Q.s. al-Maidah: 3.

${ }^{13}$ Q.s. al-An'am: 57.

${ }^{14}$ Ann KS Lambton, State and Government in Medieval Islam (Routledge, 2013).

${ }^{15}$ Imran Ahsan Khan Nyazee, Theories of Islamic Law: The Methodology of Ijtihâd (Adam Publishers, 1996), p. 112-113. 
The seed was sown by the Prophet of Muhammad (Saw) and since then, the root is embedded in the hearts of man. Like the trunk of this tree, Islamic law has a part that is fixed such as rules related to ibâdât, inheritance, marriage, divorce, and $\underline{h} u d \hat{u} d$. Like its leaves, the law has a part that changes in shape and color in every season by fresh ijtihâd. It is best illustrated by the tradition of the Prophet (Saw) when he asked his companion:

It was narrated from al-Harith Ibn 'Amr, the nephew of al-Mughîrah Ibn Shu'bah, from some of the people of Him who were companions of Mu'adh Ibn Jabal, that when the Messenger of Allah wanted to send Mu'adh to Yemen, he said: "How will you judge if a case is presented to you?" of which Mu'adh said: "I will judge in accordance with the Book of Allah." He said: "What if you do not find any (evidence) in the Book of Allah?" of which Mu'adh said: "Then in accordance with the Sunnah of the Messenger of Allah." He said: "What if you do not find any (evidence) in the Sunnah of the Messenger of Allah or in the Book of Allah?" of which Mu'adh said: "Then I shall struggle to come to the best opinion and not spare any effort in doing so." The Messenger of Allah struck him on the chest and said: "Praise be to Allah Who has guided the envoy of the Messenger of Allah to that which pleases the Messenger of Allah".

Apart from the classification above, it is important to know the purpose of the law (a $\underline{h} k \hat{a} m)$ in Islam. Al-Ghazâlî has asserted that the purpose of the law is to achieve mashlabah. The Mashlabah is not the same as "utility" 16 which is defined by Bentham, though they are similar, it is what the Lawgiver has considered being the benefit and harm. AlGhazâlî says: As for mashlahah, it is essentially an expression for the acquisition of manfa'ah (benefit) or the repulsion of mudharrah (injury, harm), but that is not what we mean by it, because of the acquisition of manfa'ah and the repulsion of mudharrah represents human goals, the welfare of humans through the attainment of these goals. What we mean by mashlahah, however, is the preservation of the end of the shar'i. ${ }^{17}$

${ }^{16}$ Ihsan Abdul Bagby, 'Utility in Classical Islamic Law: the Concept of' Maslahah' in "Usul al-Figh". 1987. Asyraf Wajdi Dusuki and Said Bouheraoua, 'The Framework of Maqasid al-Shari'ah and Its Implication for Islamic Finance', Islam and Civilisational Renewal (ICR), 2, no. 2 (2011) <https://icrjournal.org/icr/index.php/icr/article/view/174>.

${ }^{17}$ Muhammad Sulayman Ghazzali, 'Al-Mustasfa Min Ilm al-Usul', 1997, p. 216-17. Imran Ahsan Khan Nyazee, Theories of Islamic Law: The Methodology of Ijtihâd, p. 213. Moch Nurcholis, 
In an elaboration of mashla $\underline{h} a h$, al-Shâthibî contends that they are of two types: those relate to the intention of the Lawgiver and relate to the intention of the subject. The fundamental rule for the purposes of the subject is that his objectives must conform to the intention of the Lawgiver. The mashlabah or the intention of Allah Swt as laid down in Islamic law (ahkâm al-sharîah) are preservation of dîn (religion), preservation of nafs (life), preservation of nasl (progeny), preservation of 'aql (intellect), and preservation of mâl (wealth).

These five purposes are designed as dharâriyyât ${ }^{18}$ (necessities) and are the primary purposes of the law. The second is hâjjiât $t^{19}$ (complementaries), which are the additional purposes required by the primary purposes. The last category is tahsin $\hat{\imath}^{20}$ (embellishment) in the law.

Jihâd and penalties for apostasy ${ }^{21}$ are designed to protect the dîn while prayer, fasting, pilgrimage, and zakât help establish it. Life is preserved through the provision of sustenance and the maintenance of good health while it is protected through the provision of penalties (qishâsh) on those who destroy life without legal justification. Nasl is promoted through the institution of marriage and maintenance of healthy family life while penalties are provided for those who destroy it (e.g. hadd zinâ). Preservation of 'aql is achieved through the promotion of education and healthy condition for its growth while penalties are provided for those who consume the substance (e.g. hadd shurb). Preservation of wealth is achieved by encouraging its growth while hadd penalties and ta'zîr are provided for theft and other offenses such as corruption, embezzlement, etc.

In order to guarantee the existence of al-mashlahah al-dharâriyyât, two steps should be taken i.e. preservation ( $\underline{h} i f z h)$ and protection (ibqâ).

'Determinasi Mashlahah Atas Nashh: Liberasi Nalar Sharîah Najmuddîn al-Thûfí, Tafáqquh: Jurnal Penelitian dan Kajian Keislaman, 5, no. 1 (2017), p. 15-33.

18 Dhar Ëriyyât means things that are necessary for human beings in this world and the hereafter, without which humans cannot live in this word and will be in misery in Âkhirah.

19 Hajjizât means things that are needed to avoid hardship without which the human life would be difficult.

20 Tahsin $\hat{\imath}$ means things that are meant as complementary and usually relate to establishing al-akblâq al-karîmah.

21 Hasbullah, Ushûl al-Tashrî̀ al-Islâmî (Cairo: Dâr al-Fikr al- Islâmî, 1997), p. 260. 
Al-Shâthibî considers these two aspects as "what affirms its elements and establishes its foundation" and "what repels actual or expected

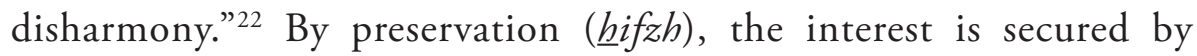
establishing what is required by the sharîah through each of its maqâshid (purposes). As protection (ibqâ), the interest is secured by preventing the destruction or corruption of the positive aspect. ${ }^{23}$

The relationship that exists between the primary purposes (almashlahah al-dharâriyyât) may be highlighted by visualizing outer shells serving or protecting the inner shell or shells. Thus, the innermost shell is represented by dinn, the shell surrounding it is that of life, which is itself surrounded by nasl and so on. Each of these primary purposes is considered a necessity that has its own supporting needs and complementary norms. These are also to be viewed as shells, one inside the other. ${ }^{24}$ But in order for these mashla $\underline{h} a h$ to be acknowledged and valued, mashla $\underline{h} a h$ must fulfil certain conditions, one of which is that it must be genuine ( as opposed to that which is plausible (wahmiyyah). Why? Looking to the nature of Islam as a religion which is universal, the mashla $\underline{b}$ ah should not be changeable or subject to the interpretation of humans and it should be the same for all human beings. The sharî'ah only protects the genuine benefits which, as al-Ghazâlî points out, are always related to the protection of the five essential interests as noted above. ${ }^{25}$

\section{Crime (al-Jarîmah)}

As discussed above, in securing the mashla $\underline{b}$ ah for human beings, sharîah takes two approaches, either by affirming its elements and establishing its foundation or repelling actual or expected disharmony. All of the commandments of sharìah aim at realizing the benefits and that all of its prohibitions are designed so as to prevent corruption. The

${ }^{22}$ Ibrahim Bin Musa al-Shâthibî, 'al-Muwâfaqât, Abû Ubaydah Mashhûr Bin Hasan'Ali Salmân, Ed.', (Mesir: Dâr Ibn 'Affân, 1997).

${ }^{23}$ Ibrahim Bin Musa al-Shâthibî, 'al-Muwâfaqât. Imran Ahsan Khan Nyazee, Theories of Islamic Law: The Methodology of Ijtihâd.

${ }^{24}$ Imran Ahsan Khan Nyazee, Theories of Islamic Law: The Methodology of Ijtihâd, p. 243.

${ }_{25}$ Mohammad Hashim Kamali, Shariah Law: An Introduction (Oneworld Publications, 2008), p. 32-36. 
acts that are obligatory (wâjib), or praiseworthy (mandûb) and permissible (mubâh) aim at realizing benefits whereas the reprehensible (makrûh) and the forbidden ( $\underline{\text { haram }}$ ) actions aim at preventing corruption and evil. ${ }^{26}$ It is in this later scope that certain acts would be considered as a crime (jarimah).

It is undoubtedly clear when we ask laymen what is a crime (jarimah). It would appear in their mind, those acts which are forbidden, which involve condemnation, blaming and evil. Similarly, crime or jarimah in the Arabic language literally conveys the meaning of those acts which are against the notion of justice and astray from the right path ${ }^{27}$. This may be concluded from various verses in the Qur'ân, for example:

Indeed, the criminals are in error and madness. ${ }^{28}$

... and do not let the hatred of a people prevent you from being just. Be just; that is nearer to righteousness... ${ }^{29}$

The word jarimah also means action with an evil intention, sin, and misdeed:

And O my people, let not [your] dissension from me cause you to be struck by that similar to what struck the people of Noah or the people of Hûd or the people of SHâlih. And the people of Lot are not far off from you. ${ }^{30}$

Verily! (During the worldly life) those who committed crimes used to laugh at those who believed. ${ }^{31}$

(O you disbelievers)! Eat and enjoy yourselves (in this worldly life) for a little while. Verily, you are the Mujrimûn (polytheists, disbelievers, sinners, criminals, etc. $)^{32}$

The above verses indicate that literally, a jarimah (crime) is, by the word of Abû Zahrah, the commission of what is prohibited and the

${ }^{26}$ Mohammad Hashim Kamali, Shariah Law: An Introduction, p. 33.

${ }^{27}$ Muhammad Abu Zahrah, 'Ushul Fiqih, Terj', Saefullah Ma’shum, dkk. (Jakarta: Pustaka Firdaus, 1994), p. 19-21.

${ }^{28}$ Al-Qamar: 47.

${ }^{29}$ Al-Maidah: 3.

${ }^{30}$ Hud: 89.

${ }^{31}$ Al-Muțaffifiin: 29.

${ }^{32}$ Al-Mursalât: 46. 
omission of an act enjoined by Allah Swt. However, this definition of crime is rather general, for ma'shiyyah (grave sin, serious offense), ithmun (guilt), dzanbun (sin) and khatha' (mistake) imply the same meaning. ${ }^{33}$

In a technical sense, the word jarimah (crime) may be defined as a legal prohibition imposed by Allah swt, whose infringement entails punishment either by hudîd or ta'zîr. ${ }^{34}$ Legal prohibition here means the commission of the forbidden act or the omission of an act that is enjoined. ${ }^{35}$ This nature shows us that an act (commission and omission) would become a crime when it is legally decreed as a crime, either expressly or impliedly. It is in consonance with the legal maxim as the conduct of the reasonable man alone is of no consequence without the support of a legal text (Nullum crimen, nulla poena sine praevia lege poenali). As for punishment, Islam has laid down that every crime has a specific punishment, either in this world or in the akhirah (hereafter). While punishment in the akhirah is a matter of Allah Swt the punishment in this world is in the hands of the government, or whoever has authority over their subjects. These conclusions are supported by several passages in the Qur'ân; to quote a few:

And we have sent down to you (O Muhammad) the Book (this Qur'ân) in truth, confirming the Scripture that came before it and Mohayminan (trustworthy in highness and a witness) over it (old Scriptures). So judge between them by what Allah has revealed, and follow not their vain desires, diverging away from the truth that has come to you ... ${ }^{36}$

O Dâwud (David)! Verily! We have placed you as a successor on earth, so judge you between men in truth (and justice) and follow not your desire for it will mislead you from the Path of Allah ... ${ }^{37}$

${ }^{33}$ Muhammad Abû Zahrah, al-Jarîmah Wa al-'Uqûbah Fî̀ al-Figh al-Islâmî: al-'Uqûubah (Ttp.: Dâr al-Fikr al-Arabî, 1966), p. 20-21.

${ }^{34}$ Abû alOrdinances of Government', Reading, UK: Garnet Publishing, Ltd, 1996, p. 285. Ramizah Wan Muhammad and Khairunnasriah Abdul Salam, 'The Concept of Retributive and Restorative Justice in Islamic Criminal Law with Reference to the Malaysian Syariah Court', Journal of Law and Judicial System, 1, no. 4 (2018), p. 8-16.

${ }^{35}$ Abd al-Qadir Audah, al-Tashrî̀ al-Jinẩi al-Islâmî̀ (Bairut: Dar al-Kutb al-Ilmiyah, 2005), p. 72.

${ }^{36}$ Al-Maidah: 48.

${ }^{37}$ Chapter 38 [Shad: These Letters (Shad Etc.) Are One of the Miracles of the Qur'an and None but Allah (Alone) Knows Their Meanings] in Verse 26. 
He said: "As for him (a disbeliever in the Oneness of Allah) who does wrong, we shall punish him; and then he will be brought back unto his Lord; Who will punish him with a terrible torment (Hell). ${ }^{38}$

I will surely punish him with a severe torment, or slaughter him unless he brings me a clear reason. ${ }^{39}$

In all, definitions of crime in sharîah are identical to the definition given for crime in modern law, which is mainly defined as the commission of an act declared wrongful, or omission of what is enjoined when the punishment is laid down by the law. Nevertheless, the differences between these two systems are unworthy of being disregarded.

As far as the nature of Islamic criminal law (al-sharîah) is concerned, it is important to note that Islamic criminal laws are essentially preventative in character and are not based solely on harsh punishment as the first resort: rather, harsher punishments are implemented as the last tool. Islamic law takes into account several steps ${ }^{40}$ in dealing with the crime before inflicting punishment upon the criminal:

a. First is a belief in the existence of God and the Hereafter. ${ }^{41}$ This relates to the practice of 'ibâdât, which is the way of communication to God. By 'ibâdâh, it increases self-awareness of the presence of the Almighty, which later on will prevent the person from committing unlawful acts and cleansing away the inner disease. The function of al-shalat (prayer) if performed perfectly will produce virtuousness, "Surely Prayer forbids indecency and evil". ${ }^{42}$ After all, what check could be more effective than this, that a man should be called upon five times a day for the remembrance of Allah Swt and made

${ }^{38}$ Chapter 18 [Al-Kahf: The Cave] in Verse 87.

${ }^{39}$ Chapter 38 [Shad: These Letters (Shad Etc.) Are One of the Miracles of the Qur'an and None but Allah (Alone) Knows Their Meanings] in Verse 26.

${ }^{40}$ Matheus Souisa, Lilik Hendrajaya, and Gunawan Handayani, 'Study on Estimates of Travel Distance, Velocity and Potential Volume of Amahusu Sliding Plane Using Energy Conservation Approach in Conjunction with Geoelectric Survey', Journal of Mathematical and Fundamental Sciences, 50, no. 2 (2018), p. 166-181 <https://doi.org/10.5614/j.math.fund. sci.2018.50.2.5>.

${ }^{41}$ M. F. al-Nabhân, Nizhâm al-Hukm Fi al-Islâm (Kuwait: Mathbu'ât Jâmi'at al-Kuwayt, 1974), p. 121-31.

${ }^{42}$ Chapter 29 [an-'Ankabût: The Spider] in Verse 45. 
to remind himself again and again that he is not wholly free and independent in this world but is the servant of One God, and his God is He Who is aware of his open as well as hidden acts, even of the most secret aims and intentions of his heart, and a time will surely come when he will have to account for all his deeds. SHalat (prayer), shaum (fasting) and zakât (alms) also prevent an جنة "ج " fasting is a shield for a Muslim, especially against natural lust. Where as zakat is to establish a society where social justice and distributional equity would prevail so that a section of the society does not discriminate and prosper at the expense of the rest of society. Thus, the religion will guide the individual through his life, either in right or in wrong. It is narrated that "a man approached the Prophet saying that he had committed a ma'shiyyah. The Prophet averted him. That man repeated his word three times and each time the Prophet averted him. Then the prayer time came after the prayers were performed the man approached the Prophet for the fourth time confessing his crime (ta'zîr). Thereupon the Prophet said: "Did you don't perform ablution and pray with us just now?" The man answered in the affirmative. The Prophet said: "You are pardoned, for performing your prayers in the best manner is in itself your atonement for your sin."

b. Secondly, it is to enjoin the establishment of justice and improve society's welfare. This involves the act of enjoining the right and forbidding the wrong. This aspect is aimed at establishing a society where modesty (الحياء) prevails within the community.

c. Thirdly, it is to curb the assimilation of crime through punishment. This is the last resort taken by Islamic law to curb the assimilation of crime in society. Therefore, the nature of punishment should deter an individual who commits the crime and those who have the inclination to commit a similar crime. When inflicting the punishment on an offender, it is important to understand that punishment in Islamic law is aimed solely for the reform of the offender. 


\section{Classification of Punishment}

Islamic jurisprudence evidently classifies crime in a different manner from what is normally understood. In other words, crime is classified based on the extent of the punishment as if the categorization of the crime is a part of the punishment. ${ }^{43}$ Islamic criminal law bases its punishment on the gravity of the crime and its threat to the primary mashlabah which we have already discussed. Punishment in Islamic law may be classified into two or three categories. They are (i) hudîd and ta'zîr punishment, or (ii) hudîd, qishâsh, and ta'zîr punishment. ${ }^{44}$ These classifications are deemed necessary as each of these categories is governed by different principles, although all of them are subject to the same general principles as laid down in sources of Islamic law. These classifications stem from two fundamental rules:

a) Firstly, Islamic law (al-sharîah) focuses its attention on safeguarding the society against crime in total disregard of the offender's person by ensuring public good is kept above the individual interest. Islamic law (al-sharîah) is strict about this punishment, and the offenses that relate to this first category are immensely grave and dangerous and any laxity in dealing with them would lead to decadence, disorder, and discontent in the society. ${ }^{45}$ However, crimes of this sort are not many. For these offenses, the standards of proof are high and require difficult conditions to be fulfilled.

b) Secondly, rule relates to the personality of the offender and aimed at his correction. The court has the power to assess the quantum of the punishment as well as the circumstances of the offender and the causes of the offense. ${ }^{46}$ If the circumstances and the causes

${ }^{43}$ The Effect of Islamic Legislation on Crime Prevention in Saudi Arabia: Proceedings of the Symposium Held in Riyadh, 16-21 Shawal 1396 A.H. (9-13 October 1976) (Saudi Arabia: Ministry of Interior, 1980).

${ }_{44}^{4}$ The Difference Is Based on the Angle the Scholars Used to Classify the Punishment. Those Who Classified Punishment in Terms of Prescribed and Unprescribed Punishment Categorized

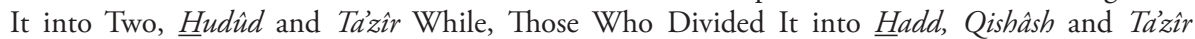
Punishments, Categorized Them in Terms of Rights.

${ }^{45}$ Abd al-Qadir Audah, al-Tashrî̀ al-Jinẩi al-Islamî.

${ }^{46}$ Tauqir Mohammad Khan and M. H. Syed, Criminal Law in Islam (Pentagon Press, 2007), p. 343. 
of the offense do not warrant any curtailment, the court should award the deserved punishment. But if it requires any curtailment in punishment then the personality, character, and behavior of the offender are taken into consideration. ${ }^{47}$

The existence of these two rules is important if the mashlahah is to be achieved. The preventive act, punishment, and limitation should be carried out only to reform the human condition as necessary for their well-being without being excessive or inadequate. If it is inadequate, the reform would not happen, and if it is excessive, it is an act of revenge and not punishment. ${ }^{48}$

\section{Hadd Punishment}

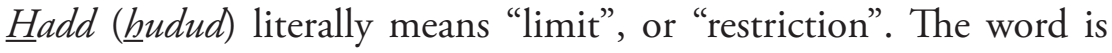
often used in Islamic literature for the bounds of acceptable behavior and the punishments for serious crimes. In Lisân al-'Arab, the origin of the word hadd is the separation between two things, the permissible and impermissible. Some of the impermissible are of such gross nature (fawâhish) that they are not to be approached, "Those are limits set by Allah, so approach them not." ${ }^{49}$ A further example of $\underline{h}$ add can be seen in inheritance law as written in the Qur'an that "Allah commands you as regards your children's (inheritance): to the male, a portion equal to that of two females;... In that which your wives leave, your share is a half if they have no child ... These are the limits set by Allah (or ordainments as regards laws of inheritance) .... ${ }^{50}$ and in marriage law as well "Forbidden to you (for marriage) are: your mothers, your daughters, your sisters, your father's sisters, your mother's sister, your brother's daughters, your sister's daughters, your foster mother who gave you suck, your foster milk suckling sisters, your wives' mother your stepdaughters under your guardianship, born of your wives to whom you have gone in-but there

${ }^{47}$ Tauqir Mohammad Khan and M. H. Syed, p. 344.

${ }^{48}$ Muhammad al-Thâhir Ibn 'Âshûr, Maqâshid al-Sharîah al-Islâmiyyah (Yordan: Dâr alNafâis, 2001), p. 337-338.

${ }^{49}$ Chapter 2 [an-Baqarah: The Cow] in Verse 187.

${ }^{50}$ Chapter 4 [al-Nisa': The Women] in Verse 11-13. 
is no sin on you if you have gone in them (to marry their daughter),the wives of your son who spring from your own loins, and two sisters in wedlock at the same time, except for what has already passed; verily, Allah is oft-giving, Most Merciful." ${ }^{1}$

As for criminal law, $\underline{\text { budud }}$ refers to the class of punishments that are fixed for certain crimes; "These are the limit ordained by God, so do not transgress them." 52 Hudûd punishments are rights belongs to God and rights belong to an individual, they are promulgated for the protection and the well-being of society against crime by any member of society. ${ }^{53}$ It is short of social engineering. No human intervention is allowed to vary the punishment, forgive them or minimize them in any way. ${ }^{54}$

Hadd punishment is strict about these punishments which are being prescribed and allows no variation by any person or by the court. It is to ensure that the moral fabric of society, the social order and peace and collective security are not jeopardized. It is not surprising that hadd punishment appears to be harsh, because hadd punishment focuses on deterring a person from committing a crime because the offenses have a direct impact that would compromise the fundamental basis of the society. ${ }^{55}$ Those who contend that such punishments are excessively harsh must consider the harmful effects on both individual and society. The focus of hadd punishment is not the offense that has been committed by the offender, but the subsequent effect produced by such action. A sâriq (a thief) would have his hand cut off if he commits theft of property of others, subject to the requirement for hadd punishment. It is not the amount which is important, but the security and serenity of the community that is the concern. People should not be put in fear that they cannot sleep without peace and their house would be broken into by thief.

\footnotetext{
${ }^{51}$ Chapter 4 [al-Nisa': The Women] in Verse 23.

${ }^{52}$ Chapter 2 [al-Baqarah: The Coq] in Verse 229.

${ }^{53}$ Muhammad 'Athiyyah al-Faitûrî, 'Fiqh al-'Uqûbah al-Haddiyyah Fi al-Tashri' al-Jinẩi al-Islâmî', Benghazi: Dâr al-Kutb al-Wathaniyyah, 1.1 (1998), p. 11-135.

${ }^{54}$ Muhammad 'Ata al-Sid, Islamic Criminal Law: The Hudûd (Malaysia, 1995), p. 30. Al-Kâsânî, Badâi' al-Shanâi' Fî̀ Tartîb al-Sharẩi (Bairut: Dâr al-Kutb al-'Ilmiyyah, 2003), p. Ix.

${ }^{55}$ Muhammad 'Ata al-Sid, Islamic Criminal Law: The Hudûd, p. 136-38.
} 
The basic idea of hadd offenses is to deter individuals and other people from committing a similar act. ${ }^{56}$ Furthermore, to assure the deterrence effect of the punishments, it should be carried out publicly. But even though this punishment is harsh and strict, nevertheless, the strict procedure must be followed before the infliction of punishment, if there is any doubt even the slightest one, the hadd punishment cannot be imposed, as in the case of al-Ghâmidiyyah who went to the Prophet to confess that she had committed adultery and asked to be stoned in order to be purged of her sin. The Prophet refuses to have her stoned to death in respect to her pregnancy. The hadd punishment was postponed until after the birth of the child. After the birth of the child, the punishment was more deferred until the child was weaned then the Prophet agreed to have her stoned and a companion agreed to take care of the child and bring him up. ${ }^{57}$ It is also narrated when a servant committed adultery, the Prophet commanded Ali ibn Abî Thâlib to flog her. But when he went to flog her, he discovered that she had recently given birth to a child, he feared that she might die if he flogged her. So he reported the matter to the Prophet, the Prophet said: "Well done! Leave her until she recovers". ${ }^{58}$

The punishment may even be replaced. It is the case when 'Umar ibn Khaththâb once stopped the execution of hadd punishment for the crime of theft (sariqah) when Muslim community in the famine years ${ }^{59}$ Another case is related to the judgment made by 'Umar who canceled the amputation of the offender's hand when he found that the offender was forced to steal in order to satisfy his hunger. ${ }^{60}$

${ }^{56}$ Muhammad 'Athiyyah al-Faitûrî, 'Fiqh al-'Uqûbah al-Haddiyyah Fi al-Tashri' al-Jinẩi al-Islâmî̀, p. 168.

${ }^{57}$ Muhammad Ibn 'Alî Muhammad al-Shaukânî, Nail al-Authâr Min Asrâri Muntaqa alAkhbâr (1st Edn, 11 Volumes). (Cairo: Dâr Ibn 'Affân, 2005).

${ }^{8}$ Muhammad Ibn 'Alî Muhạammad al-Shaukânî, Nail al-Authâr Min Asrâri Muntaqa al-Akhbâr, p. 154.

${ }^{59}$ Muhammad Sulayman Ghazzali, 'Al-Mustasfa Min Ilm al-Usul', p. 180.

${ }^{60}$ Muhammad Sulayman Ghazzali, 'Al-Mustasfa Min Ilm al-Usul', p. 182. 


\section{Qishâsh (Retaliation)}

The punishment prescribed under Islamic law for murder and personal injury is known as qishâsh or qawâd (retaliation). The infliction of injury on a culprit that is exactly equal to the injury that was inflicted on the victim. Islamic criminal law gives preference to the wronged individual when relating to qishâsh offenses.

Qishâsh has a dual nature. There is, however, an alternative punishment called diyat to be paid to the victim or his family. The resemblance of the principle of diyat (blood money) can be seen in the contemporary science of victimology, whereby victim compensation emphasizes decriminalization of the act and compensation of the victim as an alternative to the traditional punishment of incarceration.

Furthermore, the Qur'ân clearly indicates a preference for diyat (blood money) and forgiveness, which negates the application of qishâsh. Such preference illustrates the bond of continuity between temporal law and religion since the offender will be rewarded with the expiration of his sin, the verse of Qur'ân states "And We ordained for them therein a life for a life, an eye for an eye, a nose for a nose, an ear for an ear, a tooth for a tooth, and for wounds is legal retribution. But whoever gives [up his right as] charity, it is an expiation for him. And whoever does not judge by what Allah has revealed - then it is those who are the wrongdoers." ${ }^{61}$ Thus, the combination of diyat (blood money) and forgiveness produces a powerful material and spiritual inducement to forsake qishâsh.

The policy of supporting qishâsh offenses is essentially twofold: First, it does not allow the victim or his family to exact a greater level of retribution against the person who committed the violation or on his family. The second principle involves the equivalence of treatment inflicted on the offender i.e. the punishment must commensurate the offense.

${ }^{61}$ M. Cherif Bassiouni and M. Cherif Bassiouni, The Islamic Criminal Justice System (Ttp.: Oceana Publications London, 1982). 


\section{Ta'zîr}

Tazî is a form of discretionary punishment that is to be delivered for transgression against God, or against an individual for which neither, fixed punishment nor penance is prescribed. For example, al-Mawardî defines ta'zîr as "a punishment which is inflicted in case of offenses for which punishment has not been prescribed in the Qur'ân and Sunnah. The rules differ depending upon the circumstances of the offense and upon whom the punishment is inflicted. It has a common point with other punishments: it is meant as reform and deterrence which differ according to the nature of the offenses." ${ }^{62}$ This definition, therefore, excludes all crimes for hadd, kaffâra or qishâsh. It is left to the judge or the ruler to decide what type or manner of punishment should be imposed, but the sentence must not be out of proportion as the aim of ta'zîr punishment is to reform the criminal with a deterrence feature.

In Islamic legal writings, the word ta'zîr signifies a punishment that seeks to prevent the criminal from further committing crimes and also reforming the criminal. It, therefore, has a dual purpose, to deter and to reform. ${ }^{63}$ Tazir punishment is based on the individual, ${ }^{64}$ therefore, the punishment received would not be the same between two individuals since that no case would be the same but depends on the circumstances

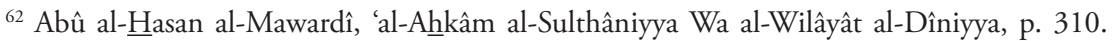

${ }^{63}$ See Muhammad Bahjat 'Atîbah, Muhâadharâ fî̀ al-Fiqh al-Jinẩi al-Islâmî (Ttp.: al-Ma'had al-Âlî li al-Dirâsât al-Islâmî, 2002), p. 391-394. See also Ahmad al-Hadharî, al-Siyâsah alJinâiyyah fî Fiqh al-'Uqûbât al-Islâmî al-Muqâran (Ttp.: Dâr al-Jîl, 1993), Vol. 1, p. 134-136.

${ }^{64}$ Quoted from Ta'zir Crimes, Ghaouti Benmelha, in The Islamic Criminal Justice System, edited by M. Cherif Bassiouni (Oceana Publications Inc, 1982), 211. See footnote: R. Charles in Le Droit Musulman (1965): Proceeding in Europe by twelve centuries, Islam acknowledges the criminal and personal liability of single individuals endowed with intellect. Elsewhere he asserts that "Muslims have revealed principles (the individualization of punishment through ta'zîr or discretionary punishment) which our legislation did not know till long afterward." in Histoire Du Droit Penal (1963). Another commentator emphasizes that Islamic Law "has further organized for the adult a system which might to a certain extent already be called a system of social defense. Aside from the Seven major crimes which are defined and foretold by the Qur'an, a certain number of offenses were left to the discretion of the judge, who must bear in mind, all at once, the infraction committed, and circumstances under which the crime has been committed, and the personality of the delinquent." in M. Ancel, La Defense Sociale Nouvelle 44 (1971). See Also Mohamed Azam Mohamed Adil, and Ahmad Badri Abdullah. "The Application of Shariah Principles of Ta'zir In Malaysian Common Law: A Maqasid-based Proposal." Islam and Civilisational Renewal (ICR) 7, no. 1 (2016). 
and the character of the offender. ${ }^{65}$ Then it is not a surprise that the judge in the Islamic criminal law has been given freedom and elasticity to think of a penalty more appropriate for the offender.

Overall, achieving justice is a necessary goal of any system of punishment and for any form of punishment, whether hadd, qishash or ta'zîr. General and special deterrence take precedence over rehabilitation in hadd and qishash punishment, as evidenced by the fact that the penalty is usually carried out publicly and immediately. As for $t a^{\prime} z \hat{\imath} r$ punishment, the consensus is that their basic goal is discipline and correction, which includes any punishment that the ruler or judge finds appropriate. ${ }^{66}$

The goals of justice and deterrence do not in any way diminish the goal of reformation for its importance in Islamic law is not a dispute. The rehabilitation of the criminal must be considered to the degree it is compatible with the actual punishment imposed. In Islamic law, punishment is not prescribed as torture to the offender, but as a disciplinary and reformative act, not only for the offender but also for the Muslim society as a whole, with a view of protecting it from vice and other shameful deeds and elevate it to the higher and more virtuous level where security, peace, respect for human relationships, fraternity and mutual understanding prevail. ${ }^{67}$

\section{Conclusion}

Modern law tries to combine all justification and treat all offenses on equal footing with the result that the legal experts have failed to arrive at an acceptable solution to the problem of the punishment and have not been able to formulate a scientific doctrine thereof. The judge has an influence on determining what justification prevails. Therefore, it is

${ }^{65}$ Abû Yảlâ Muhammad Ibn al-Husaini al-Farrầ al-Hanbalî, Al-A $\underline{h} k \hat{a} m$ al-Shulthâniyyah, edited by Muhammad Hâmid al-Faiqî (Bayrut: Dâr al-Kutb al-'Ilmiyyah, 2000), p. 279-280. See also Ahmad Fathîi Bahnasî, Al-'Uqûbah fî al-Figh al-Islâmî (Cairo: Dâr al-Shurûq, 6 editions, 1989), p. 29-30.

${ }^{66}$ M. Cherif Bassiouni and M. Cherif Bassiouni, The Islamic Criminal Justice System, p. $301-321$.

${ }^{67}$ Muhammad Rusydî Muhammad Ismầîl, Al-Jinâyât Fî al-Syarîah al-Islâmiyyah (Cairo: Dâr al-Anshâr, 1983), p. 225-26. 
not surprising that disparity of judgment and its justification spring from modern punishment system. Unlike the modern system of punishment, Islamic criminal law from the beginning of its dawn has divided offenses into three classes, each with its own primary justification. Disparity rarely happens on what justification punishment is based. Only in ta'zîr offenses do the judge has discretion on inflicting punishment, but it must be based on reformative approach.

Despite differences of both modern penology and Islamic law with regard to their approach toward punishment, it seems that both systems have similar justifications on why there must be punishment. Although the scope and character of such justifications are different the goal of punishment to be achieved is similar; the preservation of the life of society and protecting the system that complements its life.

\section{Bibliography}

Audah, Abd al-Qadir. Al-Tashrî̀ al-Jinầi al-Islâmî. Bairut: Dar al-Kutb al-Ilmiyah, 2005.

Bagby, Ihsan Abdul. 'Utility in Classical Islamic Law: the Concept of' maslahah' in "Usul Al-Fiqh", 1987.

Bassiouni, M. Cherif, and M. Cherif Bassiouni. The Islamic Criminal Justice System. Oceana Publications London, 1982.

Bukhari al-. 'Sahih Al-Bukhari: Translation by Muhammad Muhsin Khan. Riyadh', Saudi Arabia: Darussalam Publication, 1997'Âshûr, Muhammad al-Tâhir Ibn. Maqâsid al-Sharîah al-Islâmiyyah. Yordan: Dâr al-Nafâis, 2001.

Dusuki, Asyraf Wajdi, and Said Bouheraoua. 'The Framework of Maqasid al-Shari'ah and Its Implication for Islamic Finance', Islam and Civilisational Renewal (ICR), 2 (2011) <https://icrjournal.org/icr/ index.php/icr/article/view/174>.

Faitûrî, Muhammad 'Atiyyah al-. 'Fiqh al-"Uqûbah al-Haddiyyah Fi al-Tashri' al-Jinầi al-Islâmî̀, Benghazi: Dâr al-Kutb Al-Wataniyyah, 1 (1998), 11-135 Fârâbî, Abû Nasr Muhammad al-, and Rafael Ramon Guerrero, El Camino de La Felicidad. Editorial Trotta, 2002. 
Ghazi, Mahmood Ahmad. State and Legislation in Islam. Shariah Academy, International Islamic University, 2006.

Ghazzali, Muhammad Sulayman. 'Al-Mustasfa Min Ilm Al-Usul', Ttp.: Tnp., 1997.

Harding, Christopher, and Richard W. Ireland. Punishment: Rhetoric, Rule, and Practice. Ttp.: Routledge London, 1989.

Hart, H. L. A. Postscript, The Concept of Law, Edited by Penelope A. Bulloch and Joseph Raz. Oxford: Clarendon Press, 1994.

Hasbullah. Ushûl al-Tashrî̀ al-Islâmî. Cairo: Dâr al-Fikr al-Islâmî, 1997.

Ismầîl, Muhammad Rusydî Muhammad. Al-Jinâyât Fî al-Syarîah alIslâmiyyah. Cairo: Dâr al-Anshâr, 1983.

Kâsânî al-. Badâi' al-Janâi' Fî Tartîb al-Sharâii. Bairut: Dâr al-Kutb al'Ilmiyyah, 2003.

Kamali, Mohammad Hashim. Shariah Law: An Introduction. Ttp.: Oneworld Publications, 2008.

Khan, Tauqir Mohammad, and M. H. Syed. Criminal Law in Islam. Ttp.: Pentagon Press, 2007.

Lambton, Ann KS. State and Government in Medieval Islam. Ttp.: Routledge, 2013.

Mawardî, Abû al-Hasan al-. 'Al-Ahkâm al-Sultâniyya Wa al-Wilâyât alDîniyya: The Ordinances of Government', Reading, UK: Garnet Publishing, Ltd, 1996.

Muhammad, Ramizah Wan, and Khairunnasriah Abdul Salam, 'The Concept of Retributive and Restorative Justice in Islamic Criminal Law with Reference to the Malaysian Syariah Court', Journal of Law and Judicial System, 1 (2018), 8-16.

Nabhân, M. F. al-. Nizm al-Hukm Fi al-Islâm. Kuwait: Matbu'ât Jâmi'at al-Kuwayt, 1974.

Nurcholis, Moch. 'Determinasi Mashlahah Atas Nashsh; Liberasi Nalar Sharî ah Najmuddîn al-Thûfî, Tafáqquh: Jurnal Penelitian dan Kajian Keislaman, 5 (2017), 15-33. 
Nyazee, Imran Ahsan Khan. Theories of Islamic Law: The Methodology of Ijtihâd. Ttp.: Adam Publishers, 1996.

Poonawala, Ismail, 'Wealth and Poverty in the Qur'an and Traditions of the Prophet, and How Those Concepts Are Reflected in the Rasa'il Ikhwan al-Safa”, Journal of Shi'a Islamic Studies, 8 (2015), 263-87 <https://doi.org/10.1353/isl.2015.0032>.

Shaukânî, Muhammad Ibn 'Alî Muhammad al. Nail al-Autâr Min Asrâri Muntaqa al-Akhbâr (1st Edn, 11 Volumes). Cairo: Dâr Ibn 'Affân, 2005.

Sid, Muhammad 'Ata al. Islamic Criminal Law: The Hudûd. Malaysia, 1995.

Shâthibî, Ibrahim Bin Musa al-. 'Al-Muwâfaqât (Abû Ubaydah Mashhûr Bin Hasan'Ali Salmân Ed.', Mesir: Dâr Ibn’affân, 1997.

Souisa, Matheus, Lilik Hendrajaya, and Gunawan Handayani, 'Study on Estimates of Travel Distance, Velocity and Potential Volume of Amahusu Sliding Plane Using Energy Conservation Approach in Conjunction with Geoelectric Survey', Journal of Mathematical and Fundamental Sciences, 50 (2018), 166-181-181 <https://doi. org/10.5614/j.math.fund.sci.2018.50.2.5>.

Willday, J, 'Understanding Justice: An Introduction to Ideas, Perspectives and Controversies in Modern Penal Theory', Crime Prevention and Community Safety, 1 (1999), 80-81.

Zahrah, Muhammad Abû. Al-Jarîmah Wa al-'Uqûbah Fî̀ al-Fiqh al-Islâmî: al-Uqûbah. Ttp.: Dâr al-Fikr al-'Arabî, 1966.

Zahrah, Muhammad Abu, 'Ushul Fiqih, Terj', Saefullah Ma’shum, dkk. Jakarta: Pustaka Firdaus, 1994. 